$p$-ISSN 1693-9484, $e$-ISSN : 2621-8313

Majalah Ilmiah Bahari Jogja (MIBJ)

Vol. 16 No. 2, Juli 2018 (98-118)

(C) 2018 Akademi Maritim Yogyakarta

\title{
MENGANALISA KUALITAS PERAIRAN MELALUI KANDUNGAN KARBONAT PADA SEDIMEN DASAR MUARA SUNGAI SERANG KULONPROGO
}

\author{
Benny Hartanto ${ }^{*}$ \\ ${ }^{1}$ Akademi Maritim Yogyakarta, Jl. Magelang KM 4.4, Yogyakarta 55284, Indonesia \\ * Corresponding Author. E-mail: ben13hart@gmail.com. Telp: +6281328881732
}

\begin{abstract}
Abstrak
Penelitian ini merupakan studi pada kualitas perairan melalui kandungan karbonat dan bahan organik yang ditemukan dalam sedimen muara sungai Serang Kulonprogo Hasil penelitian ini bertujuan untuk memberikan informasi data tentang karbonat dan ukuran butir dari sedimen lumpur pada perairan tersebut. Selanjutnya hasil penelitian ini akan membantu dalam memantau salah satu parameter kualitas perairan di daerah ini, selain itu juga akan memberikan pertimbangan dalam usaha masyarakat sekitar pada kemungkinan budidaya tambak. Metode penelitian yang digunakan dalam penelitian ini adalah metode deskriptif dan data yang diberikan eksplosif, sedangkan pengambilan sampel dilakukan dengan menggunakan metode purposive sampling. Analisis terhadap karbonat dan bahan organik dilakukan secara kimia pada sedimen perairan, dan analisis butiran dilakukan dengan menggunakan saringan Shaker sedangkan analisis distribusi sedimen di lokasi dilakukan dengan menggunakan 4 parameter statistik : mean, standar deviasi, dan skweness kurtosis. Berdasarkan hasil analisis fisik, menunjukkan bahwa sedimen muara sungai Serang Kulonprogo terdiri dari lanau berpasir, pasir berlanau dan pasir sangat halus . Kandungan tertinggi karbonat ditemukan sekitar $16 \%$ - 16,4\% di daerah pesisir, sedangkan di daerah aliran sungai kandungan karbonatnya 9,2 \% - 9,6 \% dan di aliran sungai terkandung karbonat 9,1\% - 9,8\%. Kandungan bahan organik tertinggi terletak di daerah muara dan terendah terletak di daerah pantai, sedangkan di daerah aliran sungai memiliki kandungan bahan organik diantara keduanya. Selanjutnya sampah-sampah dan limbah organik yang terakumulasi di daerah muara sungai Serang mempengaruhi tingginya kandungan bahan organik, tetapi secara keseluruhan kandungan bahan organik di daerah muara sungai masih dalam klasifikasi sedang, ada kemungkinan dimanfaatkan untuk media budidaya perairan.
\end{abstract}

Kata kunci : Kualitas Perairan, Kandungan karbonat, Bahan Organik

\begin{abstract}
This research is a study on the waters quality observed through the content of carbonate and organic substance found in the bed sediment of Serang river estuary in Kulonprogo. The result of the research is aimed to provide the data about the content of carbonate and organic substance as well as the size of granule. Then, in turn, this result will help to monitor one of the waters quality parameters in that area, besides it will provide the consideration in running the business on fishpond cultivation. Research method applied in this research is a descriptive method and
\end{abstract}


the data is administered explosively, whereas the sampling is done using the purposive sampling method. The analysis on carbonate and organic substance is conducted chemically on the bed sediment of the waters, and the granule analysis is done using sieve shaker whereas the analysis of sediment distribution in the location is done using 4 statistic parameters : mean, deviation standard, skweness and kurtosis. The result of the physical analysis indicates that bed sediment of Serang river in Kulonprogo consists of granular silt, silted very fine and sand. The highest content of carbonate is found for about $16 \%-16,4 \%$ in coastal area, the estuary consists of $9,2 \%-9,6 \%$ and the river consists of $9,1 \%-9,8 \%$. The highest content of organic substance is found in the estuary and the lowest is found in the coastal area, whereas the content of it in the river is between them. Rubbish and organic waste accumulated in the estuary influence the level of the organic substance content, however, as a whole the content of organic substance in the estuary is in the medium classification.

Keywords : The waters quality, The content of carbonate, The content of organic.

\section{PENDAHULUAN}

\section{Latar Belakang}

Muara sungai merupakan daerah transisi antara ekosistem darat dan ekosistem laut, sehingga terjadi interaksi antara kedua ekosistem tersebut. Keadaan ini menjadikan wilayah muara sungai bersifat peka terhadap perubahan lingkungan (Odum, 1993). Sedangkan Nybakken (1988) menyatakan bahwa muara sungai adalah daerah yang kaya akan unsur hara, karena banyak menerima tambahan bahan organik dari darat. Lebih lanjut dijelaskan bahwa bahan organik yang bergerak melewati estuaria sebagian dihasilkan di estuaria itu sendiri, sebagian berasal dari darat yang dibawa aliran sungai yang masuk ke estuaria dan dari pengaruh laut.

Muara Sungai Serang, Kulonprogo merupakan salah satu perairan yang dipengaruhi oleh sampah dan limbah yang berasal dari berbagai kegiatan manusia, seperti pertanian dan pembuangan limbah rumah tangga yang ada disepanjang sungai. Kondisi ini memungkinkan terjadinya akumulasi dan peningkatan kandungan sampah dan limbah organik di daerah muara.

Untuk mengetahui lebih jauh tentang sedimen dasar perairan di muara Sungai Serang tersebut yang berkaitan dengan kualitas perairan maka perlu dilakukan penelitian dan monitoring terhadap komponen-komponen penyusunnya terutama

Majalah Ilmiah Bahari Jogja 99 | http://jurnal.amy.ac.id/index.php/MIBJ/ 
penyusun kimianya, seperti halnya parameter kandungan karbonat dan bahan organik

\section{TINJAUAN PUSTAKA}

\section{Estuarin}

Estuaria diartikan sebagai perairan semi tertutup yang mempunyai hubungan bebas air laut setelah mengalami pengenceran oleh air tawar yang berasal dari daratan (Pritchard, 1976 dalam Odum, 1993). Muara sungai menurut Nybakken (1988) didefinisikan sebagai suatu bentuk teluk di pantai yang sebagian tertutup sehingga air laut dan air tawar bertemu dan bercampur. Definisi ini memberikan arti adanya hubungan bebas antara laut dan sumber air tawar. Apabila pencampuran ini terjadi, maka air tawar dengan berat jenis lebih kecil dari air laut sehingga akan mengapung di bagian atas, tetapi seberapa besar pencampuran ini terjadi sangat tergantuing pada banyaknya faktor lingkungan yang lain, antara lain pasang-surut dan aliran sungai.

Adanya pencampuran antara air tawar yang mengalir dari daratan dengan air laut akan mengakibatkan faktor lingkungan perairan estuaria menjadi ekstrim dan merupakan daerah yang khas dimans faktor-faktor fisika seperti : salinitas, suhu, kecerahan perairan akan selalu mengalami perubahan dari waktu ke waktu. Meskipun demikian daerah estuaria merupakan daerah perikanan yang penting dan mempunyai produktivitas yang tinggi.

Menurut Hutabarat dan Evans (1985), tingginya produktivitas estuaria ini paling tidak terdapat 4 faktor yang mendukungnya yaitu :

Di daerah estuaria terdapat suatu penambahan bahan-bahan organik secara terus menerus yang berasal dari daerah aliran sungai ;

Perairan estuaria umumnya dangkal, sehingga cukup menerima sinar matahari untuk menyokong tumbuhan yang sangat banyak ;

Daerah estuaria ini merupakan tempat yang relatif kecil menerima aksi gelombang yang mengakibatkan menumpuknya detritus di dalamnya ;

Adanya pengaruh pasang surut akan mengaduk perairan sehingga bahan organik yang terdapat di dalamnya akan ikut teraduk pula.

Majalah Ilmiah Bahari Jogja 100 | http://jurnal.amy.ac.id/index.php/MIBJ/ 


\section{Sedimen}

Sedimen didefinisikan sebagai material atau pecahan dari batuan, mineral atau material organik yang ditransportasikan dari berbagai sumber dan didepositkan (diendapkan) oleh angin, udara, estuarine, dan air (Pipkin, 1977). Selain itu sedimen juga diendapkan dari materi yang melayang dalam air atau dalam bentuk kimia pada suatu tempat. Sedangkan Katili (1963) menyebutkan bahwa sedimen dibentuk dari batuan yang telah ada meliputi batuan beku, metamorf, dan batuan sedimen yang mengalami pelapukan kemudian diangkut dan diendapkan pada tempat pengendapan.

Ada 3 sumber utama dari material sedimen yang ditemukan pada permukaan dasar laut, yaitu dari daratan yang mensuplai material hancuran dari material terlarut. Sumber kedua dari laut itu sendiri dan ketiga sumbernya dari angkasa luar (Drake, 1978). Selanjutnya diuraikan lebih lanjut bahwa kebanyakan sumber dari material sedimen adalah daratan yaitu melalui proses erosi dan pelapukan yang menyebabkan pengikisan daratan untuk ditransportasikan ke laut. Pelapukan adalah aksi tumbuhan dan bakteri juga proses kimia termasuk juga penghancuran secara fisis.

Menurut Nybakken (1988), arus dan ukuran partikel merupakan faktor penting yang mempengaruhi pengendapan sedimen. Partikel yang lebih besar mengendap lebih cepat dari partikel yang lebih kecil dan arus yang kuat mampu mempertahankan partikel dalam suspensi lebih lama daripada arus yang lemah. Oleh karena itu pada tempat yang arusnya kuat sedimennya akan menjadi kasar (pasir atau kerikil), karena hanya partikel besar yang akan mengendap. Sedangkan jika perairan tenang dan arus lemah, lumpur halus akan mengendap.

Ukuran butir sedimen pada kenyataannya memiliki kisaran yang sangat luas. Untuk memudahkan penamaan butir sedimen dibuat suatu pengelompokan yang bersadarkan atas kisaran ukuran butir tertentu dari fraksi sedimen.

Secara garis besar pengelompokan sedimen terdiri dari kerikil, pasiran, lanau, dan lempung. Ukuran kerikil mempunyai diameter lebih dari $2 \mathrm{~mm}$, kisaran ukuran pasir 0,0625 $\mathrm{mm}$ sampai $2 \mathrm{~mm}$. Lanau mempunyai besaran diameter 0,004 $\mathrm{mm}$ sampai dengan $0,0625 \mathrm{~mm}$, sedangkan lempung mempunyai diameter kurang dari 
0,004 mm. Klasifikasi yang digunakan untuk penamaan dikenal dengan Skala Wentworth sebagaimana Tabel 1.

Richard (1992) menyatakan bahwa empat parameter statistik yang biasanya digunakan untuk menggambarkan detritus sedimen pada suatu daerah, yaitu : Mean (rata-rata), Standard Deviasi, Skewness, dan Kurtosis.

Tabel 1. Skala Wenthworth untuk Mengklasifikasikan Partikel Sedimen

\begin{tabular}{|l|l|}
\hline \multicolumn{1}{|c|}{ Nama Butir } & \multicolumn{1}{c|}{ Diameter Butir (mm) } \\
\hline Bongkah & $>256$ \\
\hline Berangkal & $64-256$ \\
\hline Kerakal & $4-64$ \\
\hline Kerikil & $2-4$ \\
\hline Pasir Sangat Kasar & $1-2$ \\
\hline Pasir Kasar & $0,5-1$ \\
\hline Pasir Menengah & $0,25-0,5$ \\
\hline Pasir Halus & $0,125-0,25$ \\
\hline Pasir Sangat Halus & $0,0625-0,125$ \\
\hline Lanau & $0,004-0,0625$ \\
\hline Lempung & $<0,004$ \\
\hline
\end{tabular}

Sumber : Pipkin (1977)

Mean (rata-rata), Standard Deviasi, Skewness, dan Kurtosis tersebut di atas dapat diuraikan sebagai berikut :

1. Mean

Menurut Richard (1992), mean adalah statistik rata-rata dari ukuran butir. Ukuran butir mencerminkan resistensi butiran sedimen terhadap proses pelapukan, erosi dan abrasi. Ukuran butir berhubungan dengan dinamika kondisi transportasi dan deposisi.

\section{Standard Deviasi}

Standard deviasi digunakan untuk mengukur keseragaman ukuran butir pada sampel sedimen. Standar deviasi juga disebut sebagai harga sortasi dalam sedimentologi (Richard, 1992). Nilai sortasi ini akan menggambar-kan kondisi 
selama pengendapan. Sortasi dikatakan baik jika batuan sedimen mempunyai penyebaran ukuran butir terhadap ukuran butir rat-rata pendek. Sebaiknya apabila sedimen mempunyai penyebaran ukuran butir terhadap rata-rata ukuran butir panjang disebut sortasi jelek. Adapun klasifikasi sortasi berdasarkan harga dan kelasnya dapat dilihat pada Tabel 2.

Tabel 2. Klasifikasi Sortasi

\begin{tabular}{|l|l|}
\hline \multicolumn{1}{|c|}{ Harga Sortasi } & \multicolumn{1}{c|}{ Kelas Sortasi } \\
\hline$<0,35$ & Very Well Sorted \\
\hline $0,35-0,50$ & Well Sorted \\
\hline $0,50-0,80$ & Moderately Well Sorted \\
\hline $0,80-1,40$ & Moderately Sorted \\
\hline $1,40-2,00$ & Poorly Sorted \\
\hline $2,00-2,60$ & Very Poorly Sorted \\
\hline$>2,60$ & Extremely Poorly Sorted \\
\hline
\end{tabular}

Sumber : Richard (1992)

\section{Skewness}

Skewness ialah penyimpangan detritus ukuran butir terhadap detritus normal. Detritus normal adalah detritus butir yang pada bagian tengah dari sempel mempunyai jumlah butir paling banyak. Butiran yang lebih kasar serta lebih halus tersebar di sisi kanan dan kiri dalam jumlah yang sama. Apabila dalam suatu detritus ukuran butir berlebihan partikel kasar, maka kepencengannya bernilai negatif (Folk, 1974). Klasifikasi Skewness dapat dilihat pada Tabel 3.

Tabel 3. Klasifikasi Skewness

\begin{tabular}{|l|l|}
\hline \multicolumn{1}{|c|}{ Harga Kepencengan } & \multicolumn{1}{|c|}{ Tingkat Kepencengan } \\
\hline$+1,00-+0,30$ & Menceng sangat halus \\
\hline$+0,30-+0,10$ & Menceng halus \\
\hline$+0,10--0,10$ & Menceng simetris \\
\hline$-0,10--0,30$ & Menceng kasar \\
\hline$-0,30--1,00$ & Menceng sangat kasar \\
\hline
\end{tabular}

Sumber : Folk (1974) 
4. Kurtosis

Menurut Folk (1974) kurtosis ini dapat dihitung melalui grafik kurtosis yang menggambarkan hubungan antara sortasi bagian tengah kurva dengan bagian bawah, dan ditambahkan pula bahwa bila kurva keruncingan relatif $(>1,00)$ disebut Leptokurtic, dan kurva tumpul $(<1,00)$ adalah Platykurtic harga kurtosis (keruncingan) dapat dilihat pada Tabel 4.

Tabel 4. Penilaian Harga Keruncingan

\begin{tabular}{|l|l|}
\hline \multicolumn{1}{|c|}{ Harga Keruncingan } & \multicolumn{1}{c|}{ Tingkat Keruncingan } \\
\hline$<0,67$ & Puncak sangat tumpul \\
\hline $0,67-0,90$ & Puncak tumpul \\
\hline $0,90-1,11$ & Puncuk cukupan \\
\hline $1,11-1,50$ & Puncak runcing \\
\hline $1,50-3,00$ & Puncak sangat runcing \\
\hline$>3,00$ & Puncak sangat runcing sekali \\
\hline
\end{tabular}

Sumber : Folk (1980).

\section{Karbonat Sedimen}

Menurut Nybakken (1988), kalsium karbonat berasal dari karang, alga berkapur dan organisme-organisme lain yang mengeluarkan $\mathrm{CaCO}_{3}$. Karbonat sedimen dalam laut merupakan hasil interaksi antara gas karbon dioksida dan air laut yang membentuk $\mathrm{H}_{2} \mathrm{CO}_{3}$. Asam karbonat ini kemudian beraksi dengan batu kapur kemudian membentuk karbonat $\left(\mathrm{CO}_{3}{ }^{2-}\right)$ dan bikarbonat $\left(\mathrm{HCO}^{3-}\right)(\mathrm{Odum}$, 1993). Di sedimen laut dalam karbonat banyak dihasilkan oleh sekresi organismeorganisme termasuk diantaranya foraminifera, coccolithophoridae, dan pteropoda (Chester, 1990).

Menurut Open University (1978), salinitas yang tinggi akan menyebabkan meningkatnya densitas perairan sehingga akan menyebabkan tingginya pengendapan kalsium karbonat. Selain itu juga dengan meningkatnya konsentrasi $\mathrm{H}^{+}$maka akan menyebabkan perairan menjadi asam dan sistem karbonat akan menjaga $\mathrm{pH}$ tetap dalam kisaran netral.

Majalah Ilmiah Bahari Jogja | 104 | http://jurnal.amy.ac.id/index.php/MIBJ/ 
Menurut Scoffin (1987), komposisi kandungan karbonat pada sedimen dipengaruhi oleh faktor-faktor sebagai berikut :

1. Detritus organisme bercangkang dan butiran non cangkang. Organisme yang berperan dalamnya antara lain : karang, moluska, foraminifera, alga merah berkapur, dan alga hijau berkapur.

2. Rasio produksi $\mathrm{CaCO}_{3}$ yang dipengaruhi oleh nutrien dan kandungan $\mathrm{CO}_{2}$. Daerah akumulasi $\mathrm{CaCO}_{3}$ belum tentu merupakan sumber material dari lokasi tersebut, karena patikel-partikel karbonat dapat berpindah dari sumbernya karena dipengaruhi oleh pergerakan air.

Rasio pemecahan dan transport sedimen. Hal ini dipengaruhi oleh struktur butiran, misalnya cangkang oyster lebih tahan dibandungkan dengan halimeda. Karang jenis merayap (encrusting) lebih tahan dibandingkan dengan jenis bercabang (branching). Sedangkan faktor lingkungan yang mempengaruhi pemecahan karbonat yaitu besar kecilnya energi gelombang, serta faktor yang mempengaruhi taranspor sedimen yaitu densitas butiran dan kekuaran arus.

Aspek lain yang berpengaruh misalnya aspek fisika dan biologi. Aspek fisika berupa arus dan gelombang. Dyer (1986) menjelaskan lebih jauh bahwa dengan energi gelombang yang besar akan mempercepat terbentuknya sedimen yang baru. Sedangkan aspek biologik berasal dari organisme perusak karang.

\section{MATERI DAN METODE PENELITIAN}

\section{Materi Penelitian}

Materi yang digunakan dalam penelitian ini adalah sampel sedimen dasar muara Sungai Serang Kulonprogo. Sedangkan bahan dan peralatan yang digunakan dapat dilihat pada Tabel 6 dan Tabel 7.

Tabel 6. Bahan-bahan yang Diperlukan

\begin{tabular}{|l|l|l|}
\hline No. & \multicolumn{1}{|c|}{ Bahan } & \multicolumn{1}{|c|}{ Kegunaan } \\
\hline 1. & Aquadest & Pembilas sedimen \\
\hline 2. & Larutan $\mathrm{HCL} 10 \%$ & Pendestruksi karbonat \\
\hline 3. & Larutan $\mathrm{H}_{2} \mathrm{O}_{2} 50 \%$ & Pendestruksi bahan organik \\
\hline
\end{tabular}


Tabel 7. Peralatan dengan Ukuran yang Diperlukan

\begin{tabular}{|l|l|l|l|}
\hline No. & \multicolumn{1}{|c|}{ Peralatan } & \multicolumn{1}{|c|}{ Ukuran Ketelitian } & \multicolumn{1}{c|}{ Kegunaan } \\
\hline 1. & Pipa peralon & $\phi 2$ inchi, pj $35 \mathrm{~cm}$ & Mengambil sedimen \\
\hline 2. & Plastik berklip & $1 \mathrm{~kg}$ & Wadah sampel \\
\hline 3. & Cool Box & & Wadah seluruh sampel \\
\hline 4. & Snorkling & & Pengambilan sampel \\
\hline 5. & Mangkok & & Wadah sedimen saat dioven \\
\hline 6. & Oven & $0,01 \mathrm{gr}$ & Mengeringkan sampel \\
\hline 7. & Timbangan & $0,1 \mathrm{mg}$ & Menimbang sampel \\
\hline 8. & Timbangan Meller & & Menimbang sampel \\
\hline 9. & Fumehood & $\phi 10 \mathrm{~cm}$ & Tempat melakukan reaksi \\
\hline 10. & Petridisc & 1 liter & Wadah mereaksikan \\
\hline 11. & Gelas ukur & $100 \mathrm{ml}$ & Wadah larutan \\
\hline 12. & Tabung ukur & & Mengukur vol bahan kimia \\
\hline 13. & Alat tulis & 0,$8 ; 0,4 ; 0,212 ; 0,053 \mathrm{~mm}$ & Mengayak sedimen \\
\hline 14. & Sieve Shaker & $25 \mathrm{ml}$ & Mengukur ukuran butiran \\
\hline 15. & Pipet ukur & & Wadah larutan sedimen \\
\hline 16. & Mangkok Al & & Menghaluskan sedimen \\
\hline 17. & Mortal porselin & & Mengukur suhu \\
\hline 18. & Thermometer & ${ }^{\circ} \mathrm{C}$ & Mengukur salinitas \\
\hline 19. & Refraktometer & ${ }^{\circ}{ }^{\circ}$ & Mengukur kecerahan \\
\hline 20. & Sechidisc & Meter & Mengukur pH \\
\hline 21. & pH-meter & & Mengukur kedalaman \\
\hline 22. & Tongkat duga & Meter & Mengukur kecepatan arus \\
\hline 23. & Current meter & $\mathrm{Cm} /$ det & Menentukan posisi \\
\hline 24. & Kompas & ${ }^{\circ}($ derajat $)$ & \\
\hline & & & \\
\hline
\end{tabular}

\section{Metode Penelitian}

Metode-metode yang digunakan dalam penelitian ini adalah :

1. Metode penelitian dan Pengambilan Sampling

Metode penelitian yang digunakan adalah metode deskriptif. Metode deskriptif adalah penelitian yang ditujukan untuk membuat pencanderaan secara sistematik, faktual, dan akurat mengenai faktor-faktor dan sifat-sifat suatu daerah atau populasi (Suryabrata, 1983). Ditambahkan pula bahwa data yang terakumulasi tidak diperlukan untuk membuat suatu implikasi, namun hanya untuk mencari informasi faktual serta mendapatkan justifikasi oleh keadaan atau parameter yang sedang berlangsung. 
Penelitian ini bersifat eksploratif, yaitu penelitian yang dilakukan untuk memperoleh familiaritas dari suatu fenomena atau mencari hubungan-hubungan baru agar dapat merumuskan persoalan lebih tepat dan untuk merumuskan hipotesa bila dipandang perlu. Pengambilan data dilakukan dengan menggunakan metode survey. Metode survey merupakan suatu metode pengambilan data dalam waktu yang bersamaan terhadap suatu populasi dengan cara mengamati terhadap sebagian populasi untuk dapat diambil kesimpulan secara umum dari populasi tersebut (Suwigyo, 1976).

Pengambilan sampel dilakukan dengan metode purposive sampling, yaitu dengan cara mengambil sampel bukan didasarkan atas strata, random, atau daerah, tetapi berdasarkan pertimbangan-pertimbangan tertentu. Karena muara sungai merupakan daerah pertemuan air tawar dan air laut maka pertimbangannya adalah adanya pengaruh aliran sungai dari laut terhadap muara sungai. Oleh karena itu ditentukan 3 lokasi, yaitu lokasi A diambil $100 \mathrm{~m}$ ke arah laut, dengan pertimbangan lokasi ini banyak dipengaruhi laut, lokasi B diambil pada mulut muara sungai, yang merupakan daerah pertemuan antara ait laut dan air tawar dan lokasi C diambil 100 $\mathrm{m}$ ke arah sungai, dengan pertimbangan lokasi ini banyak dipengaruhi oleh sungai dan daratan. Pada setiap lokasi ditentukan 3 stasiun, yaitu stasiun A1, A2, A3 untuk lokasi A dengan pertimbangan ada gosong di mulut muara dan jarak masingmasing stasiun $\pm 50 \mathrm{~m}$. Untuk lokasi $\mathrm{B}$ dan $\mathrm{C}$ ditentukan 3 stasiun masing-masing B1, B2, B3 dan C1, C2, C3 yang jarak antar stasiun $+20 \mathrm{~m}$. Hal ini dilakukan karena lebar sungai dan mulut muara yang terlalu besar sekitar $50 \mathrm{~m}$ sehingga diharapkan data yang diperoleh lebih akurat. Setiap pengambilan sampel pada masing-masing stasiun dilakukan 3 kali ulangan. Pengambilan sampel sedimen dilakukan secara manual, yaitu dengan cara turun langsung ke tiap-tiap lokasi. Untuk kedalaman tertentu dilakukan penyelaman ke dasar perairan. Pengambilan sampel sedimen dengan menggunakan peralon dan kemudian dimasukkan ke dalam kantung plastik berklip yang sudah diberi label sesuai dengan stasiun pengambilannya. Kemudian keseluruhan sampel tersebut dimasukkan ke dalam cool box, lalu dibawa ke laboratorium untuk dianalisa lebih lanjut.

Majalah Ilmiah Bahari Jogja 107 | http://jurnal.amy.ac.id/index.php/MIBJ/ 
Sampel sedimen dasar yang telah diperoleh selanjutnya dikeringkan selama 12 jam dengan oven pada suhu $60^{\circ} \mathrm{C}$ untuk menghilangkan kandungan air yang masih tersisa sehingga diperoleh berat yang konstan. Kemudian sampel dibagi menjadi 2 bagian, sampel pertama kurang lebih 100 gr digunakan untuk analisa ukuran butiran, sedangkan sampel kedua kurang lebih 10 gr digunakan untuk analisa karbonat dan bahan organik secara kimiawi pada sedimen dasar.

Analisa ukuran butiran

Sampel yang dianalisa sebanyak \pm 100 gr. Sampel dianalisa dengan menggunakan sieve shaker yang memiliki mesh size tertentu yaitu $0,8 \mathrm{~mm}, 0,4 \mathrm{~mm}$, 0,212 mm, dan 0,053 mm. Pengayakan dilakukan dengan menghidupkan Sieve Shaker selama 20 menit, kemudian masing-masing sedimen yang tertinggal pada setiap tingkat ayakan ditimbang (Larson, 1997), sehingga dapat dihitung prosentase ukuran butiran masing-masing sampel yang tertahan pada tiap ukuran ayakan. Hasil prosentase ukuran butiran kemudian dihitung nilai komulatifnya dan diplotkan dalam kurva. Kemudian dilakukan analisa granulometri yang dapat menggambarkan penyebaran sedimen di lokasi dengan menggunakan 4 parameter statistik, yaitu mean, standard deviasi, skewness dan kurtosis.

$$
\begin{aligned}
& \text { Mean } \quad \mathrm{Mz}=\frac{\phi 16+\phi 50+\phi 84}{3} \\
& \text { Standard Deviasi } \\
& \qquad \mathrm{g}=\frac{\phi 84-\phi 16}{2}
\end{aligned}
$$

Skewness

$$
\mathrm{SKg}=\frac{\phi 16+\phi 84-2 \phi 50}{\phi 84-\phi 16}
$$

Kurtosis

$$
\mathrm{Kg}=\frac{\phi 95-\phi 5}{2,44(\phi 75-\phi 25)}
$$

Dimana $\phi 5, \phi 16, \phi 25, \phi 50, \phi 75, \phi 84, \phi 95$ merupakan prosentase ke 5, 16, 25, $50,75,84$, dan 95 . 
Analisa karbonat

Untuk mengetahui kandungan karbonat adalah dengan cara menambahkan $\mathrm{HCl} 10 \%$ sebanyak $50 \mathrm{ml}$ pada setiap sampel sedimen sebanyak \pm 10 gr dalam wadah gelas tahan panas (Tri Dewi, 1993). Reaksi destruksi karbonat oleh $\mathrm{HCl}$ telah selesai apabila sudah tidak terbentuk lagi gelembung-gelembung gas. Tahap selanjutnya adalah pembilasan sedimen tersebut dengan menggunakan aquadest, yaitu dengan cara menambahkan aquadest pada sedimen yang bercampur $\mathrm{HCl}$ kemudian diendapkan atau di oven lagi sampai kering. Tahap pembilasan ini dilakukan sebanyak dua kali. Setelah itu sedimen di oven sampai kering untuk selanjutnya dilakukan penimbangan. Data berat yang diperoleh kemudian dimasukkan dalam rumus sebagai berikut :

$$
\begin{aligned}
& \text { Karbonat }(\%)=\frac{\mathrm{W} \text { awal }-\mathrm{W} \text { akhir }}{\mathrm{W} \text { awal }} \times 100 \% \\
& \text { Dimana } \mathrm{W}=\text { berat sampel }
\end{aligned}
$$

Analisa bahan organik

Berat sampel yang hilang selama reaksi merupakan berat karbonat yang terkandung dalam sedimen, selanjutnya residu hasil reaksi ini digunakan untuk analisa kandungan bahan organik (Tri Dewi, 1993).

Sisa sampel yang digunakan dalam reaksi yang menggunakan $\mathrm{HCl} 10 \%$ kemudian digunakan untuk analisa kandungan bahan organik sedimen. Cara kerja analisa sama dengan analisa untuk mengetahui kandungan karbonat sedimen, yang membedakan hanyalah larutan yang digunakan yaitu dengan menggunakan larutan hidrogen peroksida $\left(\mathrm{H}_{2} \mathrm{O}_{2}\right) 50 \%$. Reaksi selesai apabila sudah tidak terbentuk lagi gelembung-gelembung gas. Sedimen yang hilang selama reaksi dengan pelarut $\mathrm{H}_{2} \mathrm{O}_{2}$ ini merupakan bahan organik yang terkandung dalam sedimen (Horowitz, 1991). Berat akhir yang diperoleh kemudian dimasukkan dalam formulasi :

$$
\begin{aligned}
& \text { Bahan Organik }(\%)=\frac{\mathrm{W} \text { awal }-\mathrm{W} \text { akhir }}{\mathrm{W} \text { awal }} \times 100 \% \\
& \text { Dimana } \mathrm{W}=\text { berat sampel }
\end{aligned}
$$




\section{HASIL DAN PEMBAHASAN}

\section{Hasil Penelitian}

Hasil analisa terhadap butiran sedimen muara perairan Sungai Serang Kulonprogo secara lengkap dapat dilihat pada tabel di bawah ini .

Tabel 8. Ukuran Butiran Sedimen di muara perairan Sungai Serang Kulonprogo

\begin{tabular}{|c|c|c|c|c|c|c|c|c|c|}
\hline \multirow{3}{*}{ UKURAN } & \multicolumn{9}{|c|}{ STASIUN } \\
\hline & \multicolumn{3}{|c|}{ A } & \multicolumn{3}{|c|}{ B } & \multicolumn{3}{|c|}{$\mathrm{C}$} \\
\hline & A1 & A2 & A3 & B1 & B2 & B3 & $\mathrm{C} 1$ & $\mathrm{C} 2$ & C3 \\
\hline Pasir sangat kasar & 6 & 3 & 6 & - & - & - & - & - & - \\
\hline Pasir kasar & 9 & 11 & 10 & - & - & - & - & - & - \\
\hline Pasir menengah & 20 & 18 & 24 & 2 & 2 & 2 & 10 & 10 & 7 \\
\hline Pasir halus & 41 & 46 & 37 & 8 & 9 & 7 & 13 & 12 & 15 \\
\hline Pasir sangat halus & 18 & 14 & 16 & 18 & 37 & 14 & 31 & 29 & 28 \\
\hline Lanau & 6 & 8 & 7 & 71 & 51 & 76 & 45 & 48 & 49 \\
\hline Lempung & - & - & - & 1 & 1 & 1 & 1 & 1 & 1 \\
\hline
\end{tabular}

Sumber : Hasil Penelitian September 2017

Tabel 9. Hasil Analisa Granulometri

\begin{tabular}{|c|c|c|c|c|c|c|}
\hline \multicolumn{2}{|c|}{ STASIUN } & $\begin{array}{c}\text { RERATA } \\
\text { (MEAN) }\end{array}$ & $\begin{array}{c}\text { STANDARD } \\
\text { DEVIASI }\end{array}$ & SKEWNESS & KURTOSIS & $\begin{array}{c}\text { NAMA } \\
\text { BUTIRAN }\end{array}$ \\
\hline \multirow{4}{*}{$\mathrm{A}$} & $\mathrm{A} 1$ & 0,310 & 0,235 & 0,447 & 2,301 & Pasir \\
\cline { 2 - 7 } & $\mathrm{A} 2$ & 0,300 & 0,215 & 0,349 & 2,560 & Pasir \\
\cline { 2 - 7 } & $\mathrm{A} 3$ & 0,323 & 0,240 & 0,333 & 2,664 & Pasir \\
\hline \multirow{4}{*}{$\mathrm{B}$} & $\mathrm{B} 1$ & 0,058 & 0,038 & 0,342 & 1,874 & Lanau Berpasir \\
\cline { 2 - 7 } & $\mathrm{B} 2$ & 0,072 & 0,050 & 0,480 & 1,731 & Lanau Berpasir \\
\cline { 2 - 7 } & $\mathrm{B} 3$ & 0,057 & 0,033 & 0,182 & 2,512 & Lanau Berpasir \\
\hline \multirow{3}{*}{$\mathrm{C}$} & $\mathrm{C} 1$ & 0,105 & 0,079 & 0,631 & 1,306 & Pasir Berlanau \\
\cline { 2 - 7 } & $\mathrm{C} 2$ & 0,103 & 0,080 & 0,625 & 1,245 & Pasir Berlanau \\
\cline { 2 - 7 } & $\mathrm{C} 3$ & 0,105 & 0,075 & 0,409 & 1,234 & Pasir Berlanau \\
\hline
\end{tabular}

Sumber : Hasil Penelitian September 2017

1. Kandungan Karbonat

Berdasarkan hasil analisa terhadap kandungan karbonat dalam sedimen dasar muara perairan Sungai Serang Kulonprogo berkisar antara 9,1 \% sampai 16,4 \%. Hasil selengkapnya dapat dilihat pada Tabel 10.

Tabel 10. Kandungan Karbonat pada Sedimen Muara Sungai Serang Kulonprogo

\begin{tabular}{|c|c|c|c|c|c|c|c|c|c|}
\hline \multirow{3}{*}{ Ulangan } & \multicolumn{9}{|c|}{ Stasiun } \\
\cline { 2 - 11 } & \multicolumn{3}{|c|}{$\mathrm{A}$} & \multicolumn{3}{c|}{ B } & \multicolumn{3}{c|}{ C } \\
\cline { 2 - 11 } & $\mathrm{A} 1$ & $\mathrm{~A} 2$ & $\mathrm{~A} 3$ & $\mathrm{~B} 1$ & $\mathrm{~B} 2$ & $\mathrm{~B} 3$ & $\mathrm{C} 1$ & $\mathrm{C} 2$ & $\mathrm{C} 3$ \\
\hline 1 & 16,7 & 15,2 & 17,5 & 8,6 & 8,3 & 8,5 & 10,2 & 10,8 & 8,8 \\
\hline 2 & 14,3 & 17,8 & 14,1 & 11,2 & 8,4 & 10,4 & 8,1 & 9,3 & 11,5 \\
\hline 3 & 16,9 & 16,3 & 17,4 & 7,8 & 11,2 & 9,9 & 11,1 & 8,4 & 7,0 \\
\hline
\end{tabular}




\begin{tabular}{|l|c|c|c|c|c|c|c|c|c|}
\hline Rata-rata & 16,0 & 16,4 & 16,3 & 9,2 & 9,3 & 9,6 & 9,8 & 9,5 & 9,1 \\
\hline
\end{tabular}

Sumber : Hasil Penelitian September 2017

Parameter Lingkungan

Parameter lingkungan yang diukur meliputi parameter fisika dan kimia, diantaranya adalah suhu, salinitas, kecepatan arus, $\mathrm{pH}$, kedalaman dan kecerahan. Data parameter yang dimaksud selengkapnya dapat dilihat pada Tabel 12.

\section{Pembahasan}

Dari data yang diperoleh melalui analisa granulometri bahwa ada 3 fraksi butiran yang mendominasi sedimen dasar di lokasi penelitian, yaitu fraksi pasir, fraksi lanau berpasir dan fraksi pasir berlanau.

Tabel 12. Parameter Lingkungan yang Diukur

\begin{tabular}{|c|c|c|c|c|c|c|c|}
\hline \multirow{2}{*}{\multicolumn{2}{|c|}{ Stasiun }} & \multicolumn{6}{|c|}{ Parameter } \\
\hline & & \multirow{2}{*}{$\begin{array}{r}\begin{array}{r}\text { Suhu } \\
\left({ }^{\circ} \mathrm{C}\right)\end{array} \\
32,5 \\
\end{array}$} & \multirow{2}{*}{$\begin{array}{c}\text { Salinitas } \\
(\%)\end{array}$} & \multirow{2}{*}{$\begin{array}{c}\begin{array}{c}\text { Kec.arus } \\
(\mathrm{cm} / \mathrm{dt})\end{array} \\
8,2\end{array}$} & \multirow{2}{*}{$\frac{\mathrm{pH}}{7,7}$} & \multirow{2}{*}{$\begin{array}{c}\begin{array}{c}\text { Kedalaman } \\
(\mathrm{m})\end{array} \\
0,9\end{array}$} & \multirow{2}{*}{$\begin{array}{c}\begin{array}{c}\text { Kecerahan } \\
(\mathrm{m})\end{array} \\
0,6\end{array}$} \\
\hline & $\mathrm{A} 1$ & & & & & & \\
\hline \multirow{2}{*}{ A } & $\mathrm{A} 2$ & 32,0 & 30 & 8,0 & 7,8 & 1,0 & 0,7 \\
\hline & A3 & 32,0 & 29 & 8,5 & 7,8 & 1,0 & 0,6 \\
\hline \multirow{3}{*}{ B } & B1 & 33,0 & 17 & 4,8 & 7,4 & 0,6 & 0,4 \\
\hline & $\mathrm{B} 2$ & 32,0 & 17 & 4,7 & 7,5 & 0,7 & 0,4 \\
\hline & B3 & 31,5 & 17 & 4,8 & 7,4 & 0,6 & 0,5 \\
\hline \multirow{3}{*}{$\mathrm{C}$} & $\mathrm{C} 1$ & 32,5 & 8 & 5,2 & 7,2 & 2,0 & 0,5 \\
\hline & $\mathrm{C} 2$ & 32,0 & 7 & 5,5 & 7,1 & 2,1 & 0,5 \\
\hline & $\mathrm{C} 3$ & 32,0 & 7 & 5,5 & 7,2 & 2,0 & 0,4 \\
\hline
\end{tabular}

Sumber : Hasil Penelitian September 2017

Butiran sedimen di daerah pantai (lokasi stasiun A) didominasi oleh fraksi pasir dengan kisaran 92\% - 94\%. Menurut penamaan batuan oleh Folk (1980), batasan fraksi pasir adalah bila prosentase komulatif material pasir lebih dari $90 \%$ dan prosentase lainnya kurang dari 10\%. Fraksi pasir ini sendiri didominasi oleh pasir halus yang memiliki kisaran antara 37\% - 46\%. Untuk butiran sedimen di daerah mulut muara sungai (lokasi B) didominasi fraksi lanau berpasir dengan nilai kisaran 51\% - 76\%, sedangkan fraksi pasir berkisar antara 23\% - 48\%. Berdasarkan penamaan batuan Folk (1980), fraksi lanau berpasir adalah apabila prosentase komulatif material lanau berkisar 50\% - 90\%, sedangkan fraksi pasir berkisar antara $10 \%$ - 50\%. Sedangkan pada daerah sungai (lokasi C) butiran sedimen didominasi oleh fraksi pasir berlanau, dimana fraksi pasir berkisar antara 50\% - 54\% dan fraksi lanaunya memiliki kisaran nilai 45\% - 49\%. Selanjutnya menurut Folk (1980) fraksi 
pasir berlanau apabila prosentase komulatif material pasir yang memiliki kisaran antara 50\% - 90\%, sedangkan fraksi lanau berkisar antara 10\% - 50\%.

Hal tersebut diduga karena pada daerah pantai (lokasi stasiun A) mendapat pengaruh gelombang laut yang mempunyai kuat arus yang lebih besar, yaitu berkisar antara $8-8,5 \mathrm{~cm} / \mathrm{det}$, dibandingkan dengan dua lokasi dari stasiun lainnya yang mempunyai kisaran 4,7 - 5,5 cm/det, sehingga akan mengendapkan partikel dengan ukuran butir yang besar. Sedangkan butiran yang lebih kecil akan terus terbawa oleh pergerakan air menuju daerah muara (lokasi stasiun B) dan akan diendapkan di sana, karena perairan di daerah muara ini relatif tenang dengan kecepatan arus berkisar antara 4,7-4,8 cm/det. Hal ini terbukti dengan adanya gosong yang timbul karena penumpukan sedimen dari laut dan dari sungai di mulut muara. Hal ini jugalah yang menyebabkan butiran sedimen di daerah muara lebih kecil jika dibandingkan dengan dua lokasi lainnya. Selain dari lautan, suplai sedimen juga berasal dari daratan terutama dari aktivitas penambangan di daerah hulu yang terbawa oleh arus sungai dan terakumulasi di daerah muara.

Demikian pula halnya dengan daerah lokasi stasiun C, ukuran butirnya lebih kecil jika dibandingkan dengan lokasi stasiun A, karena perairannya yang relatif tenang dengan kecapatan arus berkisar 5,2-5,5 cm/det dan kedalaman mencapai 2 $\mathrm{m}$, sehingga partikel-partikel yang halus akan mudah terendapkan di daerah ini. Hal tersebut sesuai pendapat Nybakken (1988) yang mengatakan bahwa arus dan ukuran partikel merupakan faktor penting yang mempengaruhi pengendapan sedimen. Baker (1980) juga mengatakan bahwa sebaran dan ukuran partikel yang mengendap tergantung pada kekuatan air dalam menggerakkan dan mendistribusikan partikel tersuspensi tersebut. Selain itu juga Hutabarat dan Evans (1985) menyatakan bahwa ukuran butir yang lebih besar akan mudah terendapkan di daerah-daerah pantai.

Berdasarkan analisa granulometri menunjukkan bahwa rata-rata ukuran butir pada lokasi stasiun A berkisar antara 0,300-0,323 mm. Sedangkan berdasarkan skala Wentworth butiran ini termasuk dalam fraksi pasir menengah. Untuk lokasi stasiun B nilai rata-rata ukuran butirnya berkisar antara 0,057 - 0,072 mm, dan berdasarkan skala Wentworth butiran ini termasuk dalam fraksi lanau dan pasir 
sangat halus. Sedangkan lokasi stasiun $\mathrm{C}$ rata-rata ukuran butirnya berkisar antara $0,103-0,105 \mathrm{~mm}$ dan berdasarkan skala Wentworth butiran ini termasuk dalam fraksi pasir sangat halus.

Nilai standard deviasi pada lokasi stasiun A mempunyai kisaran antara 0,215 - 0,240 dan menurut Friedman dan Sander (1978) dalam Richard (1992) yang tergolong dalam kisaran tersebut adalah sortasi sangat baik. Untuk lokasi stasiun B nilai standard deviasinya berkisar antara 0,033 - 0,050 sehingga menurut Friedman dan Sander (1978) dalam Richard (1992) yang tergolong dalam kisaran tersebut adalah sortasi sangat baik. Sedangkan untuk lokasi stasiun C nilai standard deviasinya berkisar antara 0,080 - 0,079 sehingga menurut Friedman dan Sander (1978) dalam Richard (1992) tergolong dalam kisaran sortasi sangat baik. Hal ini menunjukkan bahwa butiran sedimen dasar di ketiga lokasi (stasiun A, B dan C) mempunyai penyebaran ukuran butir terhadap ukuran butir rata-rata pendek atau butirannya cenderung homogen.

Untuk harga kepencengan lokasi stasiun A berkisar antara 0,333 - 0,447 yang menurut Folk (1974) tergolong dalam tingkat menceng sangat halus. Untuk lokasi stasiun B harga kepencengannya berkisar antara 0,182 - 0,480 yang menurut Folk (1974) tergolong dalam kisaran tingkat menceng halus dan menceng sangat halus. Sedangkan untuk lokasi stasiun C harga kepencengannya berkisar antara 0,4090,631, dimana menurut Folk (1974) tergolong dalam tingkat menceng sangat halus. Ketiga kisaran nilai tersebut menunjukkan bahwa jumlah butiran halusnya lebih banyak daripada butiran kasarnya. Sehingga sedimen dasar pada lokasi penelitian baik daerah pantai, muara maupun sungai didominasi oleh butiran yang berukuran kecil.

Sedangkan harga kurtosis pada lokasi stasiun A berkisar antara 2,301 sampai dengan 2,664 dan menurut Folk (1974) kelas yang termasuk dalam kisaran tersebut adalah puncak kurva sangat runcing. Untuk lokasi stasiun B harga kurtosisnya berkisar 1,731 - 2,512 dan menurut Folk (1974) kelas yang termasuk dalam kisaran ini adalah puncak kurva sangat runcing. Sedangkan harga kurtosis pada lokasi stasiun C berkisar antara 1,234 - 1,306 dan menurut Folk (1974) kelas yang termasuk dalam kisaran tersebut adalah puncak kurva runcing. 
Dari data hasil pengukuran kandungan karbonat pada sedimen dasar muara perairan Sungai Serang Kulonprogo diperoleh bahwa kandungan karbonat tertinggi terdapat di daerah pantai (lokasi stasiun A) yang besar rata-rata kandungan karbonatnya berkisar antara $16 \%-16,4 \%$. Sedangakan nilai kandungan karbonat untuk daerah muara (lokasi stasiun B) dan aliran sungai (lokasi stasiun C) tidak menunjukkan perbedaan yang besar antara keduanya yaitu berkisar antara 9,1\% $9,8 \%$.

Hal ini diduga karena di daerah pantai banyak disumbang oleh organismeorganisme penghasil karbonat seperti karang, alga-alga penghasil $\mathrm{Ca}^{\mathrm{CO}_{3}}$ dan lainlain, sedangkan di daerah pantai banyak dijumpai pecahan-pecahan karang, pecahan cangkang kerang, gastropoda dan lain-lain. Selain itu juga ditemukan algaalga jenis Halimeda yang merupakan alga penghasil $\mathrm{Ca} \mathrm{CO}_{3}$, sedangkan di dua stasiun lainnya sedikit sekali bahkan kadang-kadang tidak menampakkan adanya sisa-sisa organisme penghasil $\mathrm{Ca}_{3}$. Kecerahan perairan yng hampir mencapai dasar yaitu berkisar antar 0,6-0,7 meter diduga akan mendukung pertumbuhan alga-alga berkapur yang bnyak hidup di dasar perairan. Menurut Nybakken (1988) kalsium karbonat dapat berasal dari karang, alga berkapur dan organisme lain yang mengeluarkan kalsium karbonat.

Faktor lainnya yang diduga menyebabkan tingginya kandungan karbonat di daerah pantai (lokasi stasiun A) adalah salinitas daerah tersebut yang lebih tinggi dibandingkan kedua lokasi stasiun lainnya yaitu berkisar antara 29\% - 30\% sehingga menyebabkan densitas perairannya tiggi juga. Hal ini akan mengakibatkan pengendapan $\mathrm{CaCO}_{3}$ yang tinggi (Open University, 1978). Pergerakan air juga memegang peranan penting terhadap kandungan karbonat yang pada umumnya berupa pecahan-pecahan karang atau cangkang kerang yang terbawa oleh pergerakan air dan diendapkan di daerah pantai. Selain itu juga sumber karbonat lainnya adalah hasil interaksi antara gas dioksida $\left(\mathrm{CO}_{2}\right)$ dengan air laut yang menghasilkan $\mathrm{H}_{2} \mathrm{CO}_{3}$ yang akhirnya akan terdisosiasi menjadi ion hidrogen $\left(\mathrm{H}^{+}\right)$ dan ion bikarbonat $\left(\mathrm{HCO}_{3}{ }^{-}\right)$. Ion bikarbonat ini akan terdisosiasi lagi menjadi ion hidrogen dan bikarbonat yang dalam siklus selanjutnya akan mengendap di dasar laut. Hal ini sesuai dengan pendapat Odum (1993) yang mengatakan bahwa asam 
karbonat hasil interaksi antara $\mathrm{CO}_{2}$ dengan air laut itu akan bereaksi dengan batu kapur kemudian akan membentuk karbonat $\left(\mathrm{CO}_{3}{ }^{2-}\right)$ dan bikarbonat $\left(\mathrm{HCO}_{3}{ }^{-}\right)$. Untuk daerah hulu sungai dan muara salah satu sumber karbonatnya adalah dari bongkaran batuan oleh penambang batu yang terdapat di daerah hulu sungai Sungai Serang Kulonprogo.

Rendahnya kandungan karbonat didaerah muara (lokasi stasiun B) dan hulu sungai (lokasi stasiun C) masing-masing berkisar antara 9,2\% - 9,6\% dan 9,1\% 9,8\% diduga disebabkan oleh kurangnya sumbangan kalsium karbonat dari organisme-organisme seperti karang, cangkang dan alga-alga berkapur. Selain itu juga disebabkan karena $\mathrm{pH}$ perairan yang lebih rendah sekitar 7,1 - 7,5 bila dibandingkan dengan daerah pantai (lokasi stasiun A) yang memiliki kisaran 7,7 7,8. Rendahnya $\mathrm{pH}$ ini menunjukkan bahwa perairan tersebut cenderung bersifat asam dan hal tersebut akan menyebabkan kalsium karbonat sedimen akan larut untuk menetralkan $\mathrm{pH}$ perairan. Dengan meningkatnya konsentrasi $\mathrm{H}^{+}$maka perairan akan menjadi asam ( $\mathrm{pH}$ menurun) dan sistem karbonat akan menjaga $\mathrm{pH}$ tetap dalam kisaran netral (Open University, 1978) atau dengan kata lain kelarutan kalsium karbonat akan semakin meningkat dengan bertambahnya konsentrasi ion hidrogen dalam perairan.

Berdasarkan hasil pengukuran terhadap kandungan bahan organik dalam sedimen dasar muara Sungai Serang Kulonprogo, daerah muara (lokasi stasiun B) mengandung bahan organik yang tertinggi jika dibandingkan dengan lokasi-lokasi lainnya. Rata-rata kandungan bahan organiknya berkisar antara $14,7 \%-16 \%$, nilai ini menurut Reynold dalam Sofuan (1996) termasuk dalam klasifikasi sedang. Sedangkan di daerah pantai (lokasi stasiun A) kandungan bahan organiknya hanya berkisar antara 8,3\% - 9,4\% dan sementara daerah hulu sungai (lokasi stasiun C) berkisar antara $11,5 \%$ - 14,9\%. Kedua kisaran nilai ini menurut Reynold dalam Sofuan (1996) tergolong dalam klasifikasi sedang.

Perbedaan nilai kandungan bahan organik pada sedimen di ketiga lokasi tersebut diduga disebabkan oleh beberapa faktor diantaranya adalah adanya pergerakan air, masukan dari sungai (Nybakken, 1988) maupun sumbangan dari sisa-sisa tumbuhan dan hewan benthik yang mati dan hancur (Odum, 1993).

Majalah Ilmiah Bahari Jogja 115 | http://jurnal.amy.ac.id/index.php/MIBJ/ 
Muara Sungai Serang Kulonprogo menerima bahan organik dari beberapa sumber, antara lain dari sungai Sungai Serang sendiri, dari darat, yaitu dari buangan kegiatan pertanian dan terutama dari kegiatan pertambakan yang ada di sekitar muara. Menurut Alrasjid (1988) serasah dari pohon mangrove yang tergolong cepat membusuk atau mengalami dekomposisi karena sedikit mengandung lignin merupakan sumber bahan organik yang penting bagi perairan dan substrat dasar. Selain itu juga arus yang berasal dari laut terbuka diduga banyak menyumbang bahan organik dalam bentuk partikulat (Boaden dan Seed, 1985).

Karena muara sungai merupakan pertemuan antara air laut dan sungai maka kecepatan arusnya relatif kecil karena terjadi penetralan aliran arus, yaitu berkisar antara 4,7 - 4,8 cm/det, sehingga akan menyebabkan partikel-partikel halus yang terangkut oleh aliran air baik dari laut maupun dari sungai akan terakumulasi dan mengendap di daerah ini. Partikel-partikel yang mengendap ini banyak mengandung bahan organik. Hal ini sesuai dengan pendapat Admiraal (1981) yang meyatakan bahwa sebagian besar muara sungai didominasi oleh substrat halus yang banyak mengandung bahan organik. Selain itu juga kecerahan perairan ini yang hampir mencapai dasar sekitar 0,4 - 0,5 $\mathrm{m}$ juga akan mendukung pertumbuhan organisme-organisme benthik yang ada di muara ini, baik hewan maupun tumbuhan. Keberadaan organisme-organisme ini akan dapat menambah kandungan bahan organik karena salah satu sumber penting bahan organik di perairan adalah sisa-sisa hewan dan tumbuhan benthik yang mati dan hancur.

Begitu pua halnya dengan daerah hulu sungai pergerakan air yang relatif tenang sekitar 5,2 - 5,5 cm/det dengan kedalaman mencapai $2 \mathrm{~m}$ menyebabkan mengendapnya partikel-partikel halus sehingga substrat di daerah ini halus (lumpur). Dalam substrat ini banyak mengandung bahan organik. Hal ini sesuai dengan pendapat Nybakken, (1988) yang menyatakan bahwa bahan organik banyak ditemukan pada daerah bersubstrat lumpur (ukuran butir halus). Berbeda dengan daerah pantai (lokasi stasiun A) yang mempunyai kuat arus yang lebih besar dibandingkan dengan stasiun lainnya yaitu berkisar 8,2 - 8,5 cm/det. Partikelpartikel yang diendapkan tersebut merupakan partikel-partikel berukuran besar sedangkan partikel-partikel yang berukuran halus banyak mengandung bahan 
organik dan akan terbawa oleh pergerakan air ke arah muara. Sejalan dengan pendapat Chester (1990) yang menyatakan bahwa ukuran butir halus akan ditemui dalam bentuk tersuspensi apabila terjadi energi gelombang yang besar dan mengakibatkan bahan organik yang beada di sedimen pantai tersebut ikut terangkat ke perairan dan menjadi bahan organik terlarut yang mengakibatkan bahan organik di sedimen tersebut berkurang.

\section{KESIMPULAN}

Berdasarkan hasil dan pembahasan terhadap penelitian ini dapat disimpulkan sebagai berikut :

1. Hasil analisa fisik menunjukkan bahwa butiran sedimen dasar muara perairan sungai Serang Kulonprogo berupa lanau berpasir, pasir berlanau dan pasir.

Kandungan karbonat yang tertinggi dijumpai di daerah pantai berkisar antara $16 \%$ - 16,4\%, sedangkan daerah muara hanya berkisar 9,2\% - 9,6\% dan daerah arah aliran sungai memiliki kisaran antara 9,1\% - 9,8\%.

Sampah-sampah dan limbah organik yang terakumulasi di daerah muara mempengaruhi tingginya kandungan bahan organik, tetapi secara keseluruhan kandungan bahan organik di daerah muara masih dalam klasifikasi sedang.

\section{DAFTAR PUSTAKA}

Admiraal, W. Observation and Experiment on The Population Dynamic of Epipetic Diatom from An Estuarine Mudflat Estuarine Coast.

Alrasjid, . 1988. Pelepasan Unsur Karbon Organik dan Unsur Hara Mineral Lainnya Selama Pelapukan Serasah Daun di Areal Tegakan Sisa Hutan Alam Mangrove, Sungai Sepada, Kalimantan Barat. Pusat Penelitian dan Pengembangan Hutan. Bogor.

Baker, R.A. 1980. Contaminant and Sediment. An Arbox Science Pub. Inc. Michigan.

Boaden, P.J.S., dan R. Seed. 1985. An Introduction to Coastal Ecology. Chapman and Hall. London.

Chester, R.1990. Marine Geochemistry. Unwin Hyman Ltd. London.

Day, J.W. et al. 1989. Estuarine Ecology. John Wiley and Sons, Inc.Canada. 
Drake, C.L. 1978. Oceanegraphy. Holl Rineheart and Winston. New York.

Dyer, K.R. 1996. Coastal and Estuarine Sediment Dynamics. Ohn Wiley and Sons, Inc. New York.

Folk,F.J. 1974. Petrology of Sedimentary Rocks. Hemphill Pub and Co. Austin. New York. 1980. Sedimentology of Rocks. Hemphill University. USA

Horowitz, A.J. 1991. A Primeron Sediment Trace Chemistry ; $2^{\text {nd }}$. Ed. Lewis Publiser. Chelsea.

Hutabarat, S., dan Evans, S.M. 1985. Pengantar Oseanografi. UI-Press. Jakarta.

Katili, D.R., dan J.A.Mark. 1963. Geologi. Departemen Urusan Research Nasional. Jakarta.

Larson, R. 1997. Monitoring of Coastal Enviroment Part II : Sediment Sampling and Geotechnical Methods. Journal of Coastal Reseach. Florida.

Nybakken, J.W.1988. Biologi Laut : Suatu Pendekatan Ekologis. PT.Gramedia. Jakarta.

Odum, E.P 1993. Dasar-Dasar Ekologi. Gajah Mada Press, Yogyakarta.

Open University. 1978. Ocean Chemisrty and Deep Sea Sediment. Pergamon Press. Oxford.

Pipkin, B.W. 1977. Laboratory Exercises in Oceanography. W.H.Freeman and Company. New York. 